\title{
SAFEGUARDS AND STANDARDS FOR PLEDGE FORECLOSURES*
}

Foreclosure of loans secured by pledged collateral often brings the valid interests of borrower and lender into sharp conflict. Since a borrower who has defaulted is liable for a deficiency judgment if the pledge is sold for less than his debt. ${ }^{1}$ and is entitled to the surplus if the pledge is sold for more than his debt, ${ }^{2}$ he wants the pledge sold at the highest possible price. The lender, on the other hand, has no incentive to work to obtain a surplus for the borrower. And the lender may even want to buy the collateral himself at a low price, in the hope of reselling at a profit. Secondly, the lender wants to be free to foreclose promptly upon default and to sell the pledged collateral expeditiously, since delay may prolong an unprofitable commitment of the lender's funds and increases the risk of a drop in the value of the collateral. Consequently, he demands a free hand in selecting the time, manner and place of sale. But the borrower generally wants a liberal period of time between default and the foreclosure sale in order to permit both parties to advertise and search for buyers, preserve his opportunity to redeem the pledge and put off the day of deficiency judgment. ${ }^{3}$ The borrower, however, can seldom negotiate contractual protection against the danger of the lender buying the collateral at an inadequate price or selling it hastily, since he generally has an inferior bargaining position $^{4}$ at the time the loan is made. Borrowers must therefore seek protection when the collateral is sold by invoking judicial supervision of foreclosure procedures.

In the Matter of Kiamie, 309 N.Y. 325, 130 N.E.2d 745 (1955).

1. Brown, Personal Property $\$ 132$ (2d ed. 1955) ; Jones, Collateral. Securities AND Pledges $\$ 597$ (3d ed. 1912).

2. Brown, op. cit. supra, $\$ 132$; Jones, op. cit. supra, $\$ 649$.

3. Cf. Brabner-Smith, Economic Aspects of the Deficiency Judgment, 20 VA. L. Rev. $719,721-22$ (1934) (discussing state redemption laws which give hard pressed mortgagors a certain period of time-commonly a year-in which they may redeem property sold under judicial foreclosure).

For the difference between pledges, chattel mortgages, real estate mortgages, etc., see Beown, Personal Property $\$ 128$ (2d ed. 1955) ; Tifrany, Real Property \$ 1379 (3d ed. 1939); Gilmore, American Chattel Security Devices, 2 Bus. L. Rev. 65 (1955).

4. "[A]greements ... are drawn by the pledgee usually upon expert legal advice, and are exacted frum the borrower, who by reasons of financial necessity has no other option than to accept them..." Brown, Personal Property 661 (2d ed. 1955) ; Restatenent, Security $\$ 48$, comment $e$ (1941). See Kessler, Contracts of Adhesion-Some Thoughts alout Freedom of Contract, 43 CoLusr. L. Rev. 629, 632-33 (1943) ("Standard contracts are typically used by enterprises with strong bargaining power. The weaker party, in need of the goods or services, is frequently not in a position to shop around for better terms ... because all competitors use the same clauses. His contractual intention is but a subjection mure or less voluntary to terms dictated by the stronger party, terms whose consequences are often understood only in a vague way, if at all.") ; Llewellyn, Book Review, 52 Harv. L. Rev. 700, 702-03 (1939); note 10 infra. 
The courts normally seek to balance the interests of the parties by scrutinizing the pledgee's conduct in selling the collateral. The courts do not follow the policy of rigid supervision, the judicial sale, prevalent in other types of foreclosure. ${ }^{5}$ For judicial sales are time-consuming and costly $;^{6}$ more important, since they are public auctions, judicial sales often will not bring as high a price as could be obtained by selling the pledge through the normal commercial channels of distribution. ${ }^{7}$ Instead, the pledgee may sell the collateral himself without prior judicial approval, but case law has developed rules prescribing the manner of sale. Courts forbid private sales, prohibit the pledgee from buying the collateral himself, ${ }^{8}$ and require adequate advertising and reasonable notice to the borrower. ${ }^{9}$ In virtually all pledge agreements, however, the borrower waives these common law safeguards. ${ }^{10}$ Although the waivers are normally a product of unequal bargaining positions, ${ }^{11}$ they are generally upheld on a freedom of contract rationale. ${ }^{12}$ Courts nevertheless afford the borrower

5. Brown, Personal Property \$ 133 (2d ed. 1955); Jones, Collateral Securuties AND Pledges $\$ 7589$ (3d ed. 1912). In former times the courts required judicial foreclosure on pledges as well as on mortgages. See Judge Kent's discussion in Cortelyou v. Lansing, 2 Caines Cas. 200, 204, 213 (N.X. 1805), doubting the legality of nonjudicial pledge foreclosure even at that time.

In the case of mortgages, judicial forclosure is required in some states, and it is preferred in most states. OsBoRne, MORTGAGes $\$ 318$ (1951). In bankruptcy sales, there must first be an appraisal, then public sale unless otherwise ordered by the court. MooRE, BANKRUPTCY Manual 218, 923 (1939).

6. Osborne, MoRtgages $\S 337$ n.20 (1951). See also Turner, An English Vicw of Mortgage Deficiency Judgments, 21 VA. L. Rev. 601, 603, 608 (1935) (criticizing the "expensive practice of sale through the courts rather than under a power of sale" in the mortgage field).

7. " $[I] \mathrm{t}$ is hoped that private sale will be encouraged where, as is frequently the case, private sale through commercial channels will result in higher realization on collateral for the benefit of all parties." UnIFORM COMIMERCIAL Code $\$ 9-504$, comment (1).

8. Public sale required: De Moville v. Merchants \& Farmers Bank, 233 Ala. 204, 212, 170 So. 756, 763 (1936) ; Evans v. Odum, 52 Ga. App. 453, 183 S.E. 669 (1936) ; Rykers v. Allen, 7 Hill 497, 499 (N.Y. 1844). Pledgee camot buy in: Easton v. German-American Bank, 127 U.S. 532 (1888) ; Winchester v. Joslyn, 31 Colo. 220, 72 Pac. 1079 (1903) ; Glidden v. Mechanics Nat'1 Bank, 53 Ohio St. 588, 42 N.E. 995 (1895).

9. Reasonable notice of time and place: Guinzburg v. H. W. Downs Co., 165 Mass. 467, 43 N.E. 195 (1896) ; Moss Industries Inc. v. Irving Metal Co., 142 N.J. Eq. 704, 61 A.2d 159 (1948) ; Chambers v. Carlyon, 188 Wash. 352, 62 P.2d 726 (1936). Advertisement : De Moville v. Merchants \& Farmers Bank, supra note 8; Bryson v. Rayner, 25 Mid. 423 (1866). See, generally, Brown, Personal Property 657-58 (2d ed. 1955). For summary of statutory requirements, see Note, 41 Colum. L. Rev. 1087 n.2 (1941).

10. See Seasongood, Drastic Pledge Agreements, 29 HARv. L. REv. 277, 278-79 (1916); RestateMENT, Security $\$ 48$, comment $b$ (1941). Such agreements can be found in mid-nineteenth century cases, e.g., Wilson v. J. Little \& Co., 1 Sandf. 350, 351 (N.Y. 1848 , and they reappear in similar form in nearly all modern cases dealing with pledge foreclosure.

11. See note 4 supra.

12. See cases collected in Annot., 37 A.L.R.2d 1381, 1388-97 (1954); note 10 supra. Contra, Ohio Nat'1 Bank v. Central Constr. Co., 17 App. D.C. 524, 543-44 (1901) (dictum) (waiver of all common law rules would be void as against public policy); cf. Scott v. 
some protection : they interpret pledge agreements strictly against the pledgee, ${ }^{13}$ impose on the pledgee high standards of good faith ${ }^{14}$ and readily find that the pledgee by his actions waived his own rights. ${ }^{15}$ But of these three, the doctrine of waiver by the pledgee is often the only available means of protecting the borrower. For strict interpretation can be vitiated by careful drafting and, ${ }^{16}$ except in extreme situations, good faith is hard to judge in retrospect. ${ }^{17}$

The recent case of In the Matter of Kiamie ${ }^{18}$ illustrates the inherent difficulty of balancing the interests of lender and borrower after the borrower has

National City Bank, 107 Fla. 818 , $\$ 29$, 146 So. 573, 575 (1933) (waiver of statutory notice requirement invalid) ; Burke v. Tarrant Inv. Co., 166 Okla. 179, 26 P.2d 949 (1933) (waiver of statutory requirement of public sale and notice invalid).

In the mortgage field, power of sale clauses waiving the requirement of judicial foreclosure and allowing private sale are generally held to be valid, in the absence of statutory provisions to the contrary. Durfee \& Dodderidge, Redemption from Foreclostre Sale, 23 Mich. L. REv. 825 , 832 n.2S (1925) ; 3 Jones, Mortgages $\$ 2404$ (8th ed. 1928) ; 2 Wirtsie, Mortgage Foreclosure $\S 639$ (5th ed. 1939). Contra, 1 Glenns, Mortgages $\S 100$ (1943). However, in several farm states power of sale as a method of mortgage foreclosure is prohibited by statute, and in only eighteen jurisdictions is this method generally used. Osborne, Mortgages $\$ 337$ (1951).

13. See, e.g., Union \& Mercantile Trust Co. v. Harnwell, 158 Ark. 295, 250 S.W. 321 (1923) ; (authorization of "private sale" means sale to a third party, not to the pledgee); Cole v. Manufacturers Trust Co., 164 Misc. 741, 299 N.Y. Supp. 418 (Sup. Ct. 1937) ("private sale" construed to require some negotiation with third parties, even though pledgee becomes buyer). See also Seasongood, Drastic Pledge Agreements, 29 Harv. L. REV. 277, 279-81 (1916) ; cases collected in Amnots., 37 A.L.R.2d 1381, 1390-92 (1954); 76 A.L.R. 705, 718-22 (1932).

14. Ohio Nat'l Bank v. Central Constr. Co., 17 App. D.C. 524, 544 (1901) ("utmost fairness and good faith"); Coleman v. Solomon, 225 Ala. 407, 143 So. 576 (1932) (sale must be fair and open); United Bank \& Trust Co. v. Jones, 30 Ariz. 557, 564-65, 249 Pac. 747,749 (1926) (pledgee "bound to the observance of good faith and a suitable regard for the interests of his principal") ; Highland v. Davis, 119 W. Va. 501, 513-14, 195 S.E. 604, 610 (1937) (good faith and a reasonable degree of skill and diligence to secure a fair price). Courts often speak of the pledgee as in a "trust" or "trustlike relationship." Dibert v. Wernicke, 214 Fed. 673, 680 (6th Cir. 1914); Highland v. Davis, supra at 513, 195 S.E. at 610. See also Brown, Personal Property 662-63 (2d ed. 1955) (though pledgee not technically a trustee, general analogy holds true); Seasongood, Drastic Pledge Agreements, 29) HaRv. L. Rev. 277, 281 (1916).

15. E.g., Clapp v. Associated Depositors, Inc., 33 F. Supp. 686, 689 (D. Ohio 1940) (pledge agreement gave right to sell at public or private sale, without advertisement; by electing to sell at public sale, pledgee waives right to sell without advertisement); Melvindale State Bank v. Eckfeld, 283 Mich. 179, 277 N.W. 876 (1938) (gratuitous promise to sell collateral immediately waived contractual right to sell at any time); Toplitz v. Bauer, 161 N.Y. 325, 55 N.E. 1059 (1900) (gratuitous time extension without specifying new due date waives the pledgee's right to foreclose without notice).

16. See, e.g., Llewellyn, Book Review, 52 HARv. L. REv. 700, 702-03 (1939).

17. The burden is generally on the borrower to show the lender's bad faith. See Camloridge Sav. Bank v. Cronin, 289 Mass. 379, 194 N.E. 289 (1935). But see King v. D. Sullivan \& Co., 92 S.W. 51 (Tex. Civ. App. 1906) (burden shifts to pledgee if it is shown that he sold for less than value of collateral).

18. 309 N.Y. 325,130 N.E.2d 745 (1955). 
waived his common law safeguards. In the summer of 1933 Kiamie pledged all the outstanding shares of four small real estate holding corporations to secure a $\$ 26,000$ bank loan. The pledge agreement gave the bank the right, upon default, to sell "at any time or times ... at public or private sale ... without demand, advertisement or notice, which are hereby waived," and to purchase at such a sale. In November, 1933, the bank had the stocks sold by the New York City auctioneer who handled most sales of this type. ${ }^{19}$ The day before the sale and the day of the sale an advertisement in two New York City morning newspapers had listed the stocks among about thirty other items to be sold by the auctioneer. The only description was the number of shares, the names of the corporations and the state of their incorporation. The bank itself bid them in for $\$ 5,000$. The New York Court of Appeals invalidated the sale on the ground that the advertisement was inadequate, suggesting that it might have shown what kind of business the corporations conducted, what their assets and liabilities were, and that the shares offered for sale constituted all the outstanding capital stock of the corporations. ${ }^{20}$

19. Adrian H. Muller \& Son. The surrogate held that "the proof also indicates that the place of the public sale of the stock was one at which securities of that nature were customarily sold." In the Matter of Kiamie, 191 Misc. 179, 186, 76 N.Y.S.2d 684, 691 (Surr. Ct. 1948), rev'd other grounds, 309 N.Y. 325, 130 N.E.2d 745 (1955). See also Farmers' Nat'l Bank v. Venner, 192 Mass. 531, 536-37, 78 N.E. 540 (1906) (describing same firm as largest auction business of securities in New York City). A survey of the Wall Street Journal of the period shows that this auctioneer was virtually the only one to advertise such sales.

20. The court remitted the sale to the Surrogate's Court where very interesting damage problems might be raised. A defective sale at which the pledgee himself becomes the buyer is, in the absence of fraud, voidable, and does not constitute conversion. Jones v. National Chautauqua County Bank, 272 App. Div. 521, 74 N.Y.S.2d 498 (4th Dep't 1947) ; cases collected, Annot., 37 A.L.R.2d 1381, 1386 (1954) ; Brown, Personal Property 663 (2d ed. 1955) ; Restatement, Security \$ 51 (1941). Contra, Linker v. Batavian Nat'1 Bank, 244 Wis. 459,12 N.W.2d 721 (1944). However, the bank later sold the shares to third persons at unadvertised private sales. The surrogate may hold that these private sales were valid, even though the prior public sale was invalid. See note 35 infra. The pledgor then can recover the difference between sale price and the amount of the loan less costs and interest. However, if the private sale is also held improper, the bank would be liable for conversion. Brown, op. cit. supra \& 136; Jones, Collateral Securities and Pledges $\$ 571$ (3d ed. 1912). The damages for conversion are, under the New York rule, the highest market value of the securities during a reasonable interval after plaintiff learns of the wrong. Baker v. Drake, 53 N.Y. 211 (1873); German v. Snedeker, 257 App. Div. 596, 13 N.Y.S.2d 237 (1st Dep't), aff'd, 281 N.Y. 832, 24 N.E.2d 492 (1939); Jones v. National Chautauqua County Bank, supra; 1 Bondright, Valuation of ProperTy 32021 (1937) ; MCCoraick, Danaages 188-89 (1935) (reasonable period interpreted as a few weeks or at most, two months).

In view of the post-war real estate boom, the Kiamie estate might seek a higher measure of damages on the theory that New York should abandon the reasonable time rule and revert to its former rule of highest value between conversion and trial. See Burt v. Dutcher, 34 N.Y. 492 (1866) ; Lobdell v. Stowell, 51 N.Y. 70 (1872) ; Groat v. Gile, 51 N.Y. 431 (1873). This rule has been used by two lower courts despite Baker v. Drake, supra, and the numerous cases following it. Kavanaugh v. McIntyre, 74 Misc. 222, 133 N.Y. Supp. 
Although the Kiamie decision may be interpreted as following the precedent established in a few jurisdictions, it may also be interpreted as imposing new restrictions on the pledgee's freedom of contract. Kiamie is, in a narrow sense, identical to some prior case law: a waiver of advertising applies only if the sale is private; if the pledgee elects to sell publicly, inadequate advertising voids the sale. ${ }^{21}$ But Kiamie differs in two broader aspects. In nearly all prior cases of this type, insufficient advertising was accompanied by at least a suggestion of bad faith or inadequate price. ${ }^{22}$ And these cases all reasoned that advertising was a necessary element of a public sale. ${ }^{23}$ But instead of referring to the economic consequences, real or assumed, of inadequate advertising, the Kiamie court invalidated the sale solely on principle. It specifically rejected any implication of bad faith ${ }^{24}$ and refused to overturn the lower court's finding that the evidence failed to establish inadequacy of price. ${ }^{25}$ And the court in fact gave no suggestion that it required a fair amount of advertisement only because the bank elected to sell publicly. Kiamie consequently can be interpreted as bringing advertisement within the category of judicial safeguards

679 (Sup. Ct. 1911) ; P1ymouth Rubber Co. v. Knott, 114 Misc. 695, 187 N.Y. Supp. 914 (Mun. Ct. 1921).

The statute of limitations simplifies the damages problem in most cases, see N.Y. Crv. PRAC. ACT $\$ \$ 48,49$, but it does not bar the claim by the Kiamie estate. Although only recently litigated, the action was brought within the requisite period. 309 N.Y. at 328, 130 N.E.2d at 746.

21. See cases cited notes 22 and 23 infra.

22. Eppert v. Lowish, 91 Ind. App. 231, 168 N.E. 616 (1929) (well secured bonds worth $\$ 26,000$ sold for $\$ 15,000)$; Tennent v. Union Cent. Life Ins. Co., 133 Mo. App. 345, 112 S.W. 754 (1908) (insurance company sold to itself in own office policy worth $\$ 244$ for $\$ 155)$; Huntingdon Valley Trust Co. v. Norristown-Penn Trust Co., 329 Pa. 356, 196 Atl. $\$ 21$ (1938) (bank sold to itself in own office mortgage for $\$ 25$, later resold at a profit of $\$ 13,000)$. But sie Clapp v. Assaciated Depositors, 33 F. Supp. 686 (D. Ohio 1940) (no indication that price was not fair market value; however, sale was held in pledgee's office with only employees present and pledgee made large profit on resale); Union \& Mercantile Trust Co. v. Harnwell, 158 Ark. 295, 250 S.W. 321 (1923) (same). In almost all such cases of invalidation the pledgee himself bought the collateral.

23. E.g., Union \& Mercantile Trust Co. v. Harnwell, 158 Ark. 295, 303, 250 S.W. 321 (1923) (public sale without advertising would render pledge contract self-contradictory); Mechanics \& Metals Nat'l Bank v. Pingree, 40 Idaho 118, 232 Pac. 5 (1924) (election to sell at public sale is waiver of right to sell without advertisement); Amarillo Nat'l Bank v. Harrington, 62 Tex. Civ. App. 179, 181, 131 S.W. 231, 232 (1910) (advertising essential at public sale to attract bidders since auctioneer must sell even if the highest bid is wholly inadequate). Contra, In re Mertens, $144 \mathrm{Fed} .818$ (2d Cir. 1906), aff'd sub nom. Hiscock v. Varick Bank, 206 U.S. 28 (1907) (interpreting New York law to allow unadvertised public sale).

24. 309 N.Y. at 331,130 N.E.2d at 748.

25. 191 Misc. at 187, 76 N.Y.S.2d at 691. This finding was before the Court of Appeals; wne of the grounds of appeal was that the surrogate had erroneously excluded evidence tending to show that the pledgee bank and its agents profited greatly by the resale of the collateral. Brief for Appellants, pp. 70-73, In the Matter of Kiamie, 309 N.Y. 325, 130 N.E.2d 745 (1955). The Court of Appeals, however, mentioned neither the question of adequacy of price nor this probative evidence. 
which cannot be waived by the borrower. ${ }^{26}$ And this interpretation may extend to the other common law safeguards; it may restrict the pledgee's freedom to bargain for the power to sell without notice to the pledgor, to sell quickly, or even to sell privately. ${ }^{27}$

Regardless of the interpretation followed, Kiamie should not apply to the sale of collateral whenever its value can be readily ascertained from published market reports. ${ }^{28}$ When there is a recognized market for the collateral, the pledgee can by definition find willing buyers at the market price, but has virtually no possibility of obtaining a higher price. ${ }^{29}$ In these cases, therefore. price alone is normally an adequate criterion for judging the sale,,$^{30}$ provided the pledgee is required to give notice to the pledgor of the time and manner

26. There is language in the opinion which encourages such an interpretation: "the power conferred on the pledgee by this note to sell at public or private sale and without advertisement or notice, leaves intact the law's own requirement that every such sale be conducted in good faith. ... While the pledgee under such an agreement may become the purchaser ..., his exercise of that right makes it all the more necessary that the law's insistence on ample notice [by advertisement] be heeded." 309 N.Y. at 331, 130 N.E.2d at 748. See 11 The Record of the Ass'n of the Bar of the Crty of New York 84,86 (1956) ("the Court ... may well have established standards which must be complied with in order to safely sell stock of little known corporations").

27. But this interpretation cannot be extended to rule out all waivers in the pledge agreement; the court held that, although an unadvertised public sale was invalid, the pledge agreement had effectively waived the pledgor's right to any specific statutory standard of advertising. For this reason, the court declined to decide whether in the absence of a waiver the advertisement requirement of $\$ 202$ of the New York Lien Law wonld apply. 309 N.Y. at 331,130 N.E.2d at 748.

28. Since they represent liquidated claims, savings bank pass books and life insurance policies should not be subject to the Kiamie court's reasoning whenever the debtors' free reserves or asset/liability ratios are regulated by state or federal law. Their value is then readily determinable-the total deposit recorded in the pass book or the cash surrender value stated in the policy. Cf. Hamilton v. R. S. Dickson \& Co., S5 F.2d 107 (2d Cir. 1907); UnIForM COMimMerctal CODE \$3-802(1).

This proposal, together with the exception suggested in note 52 infra, will probably exclude most pledge foreclosures from the Kiamie rationale. See letter from Harold $\mathrm{H}$. Kaufman, Vice-President, Manufacturers Trust Co., New York, June 7, 1956, on file with Yale Law Journal: "The collateral most commonly pledged will consist of marketable stocks and bonds and to a lesser degree . . . of life insurance policies, savings bank pass books, warehouse receipts, etc. It is unusual to take stock of closely held corporations."

29. But see Cole v. Manufacturers Trust Co., 164 Misc. 741, 747, 750, 299 N.Y. Supp. $418,427,430$ (Sup. Ct. 1937). The court invalidated a private sale at which the pledget sold the collateral, stocks and bonds, to himself at market price. The court held that market price is not necessarily the highest price obtainable since an interested party desiring to keep the securities off the market or to secure control of a corporation might pay more than market price. See also 1 Bonbright, Valuation of Property 26 (1937). The fact that the pledgor had not been notified before the sale seems a better reason for invalidation: as the court pointed out, the date of private sale is difficult to ascertain, and the pledgec might claim to have sold at a date when the market was low.

30. See Klapp v. Bache, 229 App. Div. 415, 242 N.Y. Supp. 155 (3d Dep't), aff'd, 255 N.Y. 550,175 N.E. 308 (1930); Estes v. Perkins, 137 App. Div. 367,121 N.Y. Supp. 714 (4th Dep't 1910). 
of sale. ${ }^{31}$ For the pledgor can, after receiving notice, ascertain the market price from published reports and, if the pledgee sells for less, establish his legal claim to the difference. ${ }^{32}$ Thus, the lender should be required only to give the pledgor notice of the sale at the time the sale is made; for any additional requirements, such as advertisement, would harm both lenders and borrowers by needlessly increasing the costs of foreclosure. Of course the sale itself is always subject to an overriding requirement of commercial reasonableness. The pledgor cannot, for example, break the market by dumping large blocks of stock, $^{33}$ nor deliberately choose the weaker of two convenient markets. ${ }^{34}$

However, if the collateral has no such readily ascertainable market value, neither interpretation of Kiamie is adequate. The narrow interpretation will continue the anomalous results reached in prior cases: if the pledgee buys the collateral at an unadvertised public sale, the sale is invalid but the pledgee can later sell the same collateral privately without advertisement. ${ }^{35}$ Nor have adequacy of price and good faith been satisfactory criteria for judging the pledgee's conduct. ${ }^{36}$ For a pledgee may act in good faith and still not obtain an adequate

31. See note 22 supra. Contra, Estes v. Perkins, supra note 30.

32. Southern Exchange Bank v. Langston, 33 Ga. App. 477, 127 S.E. 230 (1925) ; Cox v. Republic Nat'l Co., 112 S.W.2d 300 (Tex. Civ. App. 1937) ; Brukas v. Union Nat'l Bank and Trust Co., $345 \mathrm{~Pa} .15,26 \mathrm{~A} .2 \mathrm{~d} 663$ (1942) (dictum). Courts generally admit into evidence published market reports when they appear to be reliable. 6 WIGMroRe, EVIDENCE $\S 1704$ (3d ed. 1940); Comment, 45 MIrch. L. Rev. 748 (1947). See, e.g., Webber v. Umback, 125 Kan. 117, 263 Pac. 786 (1928) ; Friedman Iron \& Supply Co. v. J. B. Beaird Co., 222 La. 627, 63 So. 2d 144 (1953).

Since the pledgor can replace his readily marketable collateral, he will be made whole in these cases by the difference between the market price and the sale price, plus interest from the date of sale. A conversion rule of damages which may, in addition, make the pledgee liable to the pledgor for an increase in the market price after the sale, see note 20 supra, would not be compensatory but punitive.

33. Hudgens v. Chamberlain, $161 \mathrm{Cal} .710,120 \mathrm{Pac}$. 422 (1911) (by dumping all pledged shares on market at one time, pledgee depreciated price to two thirds normal value; pledgor could recover damage suffered).

34. Jennings v. Moore, 189 Mass. 197, 75 N.E. 214 (1905) (stock of local New Hampshire railroad sold in Boston, where unknown, for one-tenth of market value in New Hampshire); sec Mechanics \& Metals Nat'l Bank v. Pingree, 40 Idaho 118, 232 Pac. 5 (1924) (pledgor sold promissory notes in New York, makers were well known in Idaho).

35. Clapp v. Associated Depositors, 33 F. Supp. 686, 690-91 (D. Ohio 1940) ; Huntingdon Valley Trust Co. v. Norristown-Pern Trust Co., 329 Pa. 356, 196 At1. 821 (1938). Contra, Lowe v. Ozmun, 3 Cal. App. 387, 86 Pac. 729 (1906).

36. Inadequacy of price alone will not invalidate a sale. Wade v. Markwell \& Co., 118 Cal. App. 2d 410, 258 P.2d 497 (1953); Castro v. Linchitz, 297 Mass. 381, 8 N.E.2d 744 (1937); General Phoenix Corp. v. Cabot, 300 N.Y. 87, 89 N.E.2d 238 (1949) ; Brown, Personal. Property 666-67 (2d ed. 1955); see Uniform Commerctal Code $\$ 9-507(2)$. But sec Cox v. Republic Nat'l Co., 112 S.W.2d 300, 305 (Tex. Civ. App. 1937) (sale invalidated because stocks were sold for about $93 \%$ of "reasonable market value"); cf. Brukas v. Union Nat'l Bank \& Trust Co., 345 Pa. 15, 26 A.2d 663 (1942) (readily marketable collateral must be sold for market price). This principle is also followed in cases of nonjudicial foreclosure of mortgages under power of sale clauses. 5 TIFFANY, REAL Property $\$ 1550$ (3d ed. 1939). Yet, a grossly inadequate price may create an inference of 
price, ${ }^{37}$ and it is often extremely difficult to determine what a fair price would have been. ${ }^{38}$ Moreover, the pledgee may, as in Kiamie, act in good faith by following prevailing commercial practice ${ }^{39}$ but fail to safeguard the borrower's interests because prevailing practice is objectionable.

A better solution can be reached by accepting Kiamie's broader implication -a clause in the pledge agreement waiving advertisement is invalid. The courts have long recognized that freedom of contract will not justify every waiver by the borrower; they refuse to recognize a waiver of the pledgor's equity of redemption ${ }^{40}$ and, in a few cases, his right to public sale. ${ }^{41}$ Other waivers in the pledge agreement should be similarly invalidated. For as long: as lenders are free to broaden the waiver language of their pledge agreements.

fraud or bad faith. See Coleman v. Solomon, 225 .4la. 407, 143 So. 576 (1932); Wade v. Markwell \& Co., 118 Cal. App. 2d 410, 258 P.2d 497 (1953) ; Jennings v. Moore, 189 Mass. 197,75 N.E. 214 (1905).

37. See, e.g., Winchester Rock \& Brick Co. v. Murdough, 233 Mass, 50, 123 N.E. 344 (1919) ; Continental \& Commercial Nat'l Bank v. Ricker, 330 Mo. 75, 49 S.W.2d 20 (1932).

38. See 1 Bonkright, Valuatron of Property $22-39$ (1937) ; $c f$. Clapp v. Associatcd Depositors, 33 F. Supp. 686, 689-90 (D. Ohio 1940). This is especially true when, as in the present case, there is a long time lapse between sale and trial. In the Matter of Kiamie, 191 Misc. 179, 187, 76 N.Y.S.2d 684, 691 (Surr. Ct. 1948), rev'd other grounds, 309 N.Y. 325,130 N.E.2d 745 (1955). The pledgor generally has the burden of proving inadequacy of price. Hiscock v. Varick Bank, 206 U.S. 28, 39 (1907).

39. 191 Misc. at 186, 76 N.Y.S.2d at 691. See Seasongood, Drastic Pledgr Agreements, 29 HARv. L. Rev. 277, 282 (1916) (indicating that the kind of advertisement used in the present case is a "common form").

Of course, the fact that such advertisement was common practice does nut mean that . it was reasonable. In the December 27, 1933 issue of the Wall Street Journal, for example, a single advertisement lists some 300 items, all in very small print. Although stocks and bonds were the most common items, automobiles, patent rights, personal notes, contract rights, country club memberships and other heterogeneous items were frequently conglomerated. Such advertisements, undoultedly ill-designed to attract inquiry, seem little more than a formality.

40. See, e.g., Alcolea v. Smith, 150 La. 482, 90 So. 769 (1921) (traces invalidity oi forfeiture clause back to edict of Constantine) ; Williams v. Schmeltz. 14 S.W.2d 966, 967 (Mo. App. 1929) ; Brown, Persondal Property 661 (2d ed. 1955). The same rule is fol. lowed in mortgage cases. See, e.g., Mooney v. Byrne, 163 N.Y. 86,58 N.E. 1090 (1900); Cohn v. Bridgeport Plumbing Supply Co., 96 Conn. 696, 115 Atl. 328 (1921).

For validity of forfeiture agreements concluded subsequent to original transaction, sec note 42 infra.

41. This is the minority view, and it is limited to cases where the pledgee bought the collateral himself. See, c.g., United Bank \& Trust Co. r. Jones, 30 Ariz. 557, 249 Pac. 747 (1926) ; Union \& Mercantile Trust Co. v. Harnwell, 158 Ark. 295, 250 S.W. 321 (1923). The majority allow private sale to the pledgee, if the pledge agreement so provides. IE.q., Englert v. First Nat'l Bank, 333 Pa. 297, 5 A.2d 136 (1939); cases collected in Brunv, Personal Property 664 n.42 (2d ed. 1955). Some courts qualify their appruval, however. Cole v. Manufacturers Trust Co., 164 Misc. 741, 299 N.Y. Supp. 418 (Sup. (t. 1937) (n. private sale to pledgee unless well advertised, thus giving third parties opportunity to make offers).

For similar statutory restrictions on the pledgee's freedom of contract, see note 12 supra. 
the courts will have increasing difficulty in protecting borrowers from abuse; they can only distort the meaning of the contract or include a broader range of conduct within the definitions of bad faith and waiver by the lender. Instead of these undisciplined devices, the borrower should be protected by forthright rejection of waiver clauses. ${ }^{42}$ But the Kianie court did not complete the analysis. If the borrower's safeguards can not be waived, they should not become an unreasonable burden on the lender. The courts should require no more than necessary to insure adequate protection of the borrower. And these requirements should be clearly defined. ${ }^{43}$ Imprecise standards encourage litigation and may lead commercial lending institutions to take unnecessary precautions $\mathbf{;}^{44}$ each of these consequences will increase the cost of loans.

42. Uniforar COMMercial. CODE $\$ \S 9-501(3), 9-504(2)$ (invalidating waivers of the pledgor's right to notice) ; cf. Uniforar Conditional Sales Acr $\$ 13$ (same for conditional vendee); Uniform TRUst Receipts ACT $\$ 6(3)$ (b) (same for trustee). Contra, Seasongood, Drastic Pledge Agreements, 29 HARv. L. Rev. 277, 279 (1916) ("Notwithstanding, however, such agreements may appear in some aspects harsh and drastic, the courts should, and do, attempt to carry out rather than strike down such compacts, preserving the rights of the pledgor by strict construction and by requiring exercise, in his hehalf, of the utmost good faith.").

Although waiver in the pledge agreement should be disallowed, it seems desirable to permit the pledgor to enter a waiver agreement after, or just before, default. Both pledgor and pledgee may then agree that a particular speedy and inexpensive way of selling the collateral would be most advantageous to both parties. An agreement of this type should be upheld, particularly since arm's length negotiation seems more likely after the borrower has received his loan. But if a post-loan waiver is given in consideration of additional credit or a time extension, it should be invalidated unless the waiver appears to be commercially reasonable for both parties.

Restatement, Security $\$ 55$ seems to consider the parties' bargaining position more nearly equal after the loan has been concluded. It permits an agreement made at that time which provides that the collateral may be retained hy the pledgee and applied on the debt. The hurden is then on the pledgee to show that the agreement is free from fraud and uppressiun. See Cunningham v. Jones, $108 \mathrm{Ky} .728,57$ S.W. 488 (1900), and cases collected Annut., 24 A.L.R. \$29-31 (1923). See also Uniform CoMmercial Code \$ 9-505(2) (secured party may give notice to the debtor of a proposal to keep the security in satisfaction of the debt; unless debtor objects within thirty days, creditor may do so).

43. For example, Kiamic refused to establish rules by which lenders may, in the future, guide their conduct: "[W]e find it impossible to announce detailed rules applicable to every such notice of sale." More important, while the court noted several items of information which might have been included in the advertisement, it carefully avoided saying that all of these items were essential, or, on the other hand, would have been sufficient. 309 N.Y. at 331,130 N.E.2d at 748.

44. Commercial lenders rightly demand a high degree of certainty. Brief for the New Yorl: State Bankers Association, as Amicus Curiae, in Support of Motion for Leave to Reargue, p. 9, In the Matter of Kiamie, rearg. denied, 1 N.Y.2d 859 (1956). As an indication of the uncertainty created, see 11 THF Recorn of THE Ass's of THE BAR OF THE CITY of NEW YoRK 84, 86 (1956) ("These standards may require placing extremely extensive information in published notices and may puse serious questions in connection with the drafting of notices."). See also McNaughton, A Business .Man's Opinion of the Law, 6 ORE. L. Kev. 108, 111 (1920). 
First, private sales should be permitted. Allowing only public sales may seem an attractive rule, for it would greatly reduce the possibility of controversy later arising between lender and borrower. Indeed, this approach has been adopted in French law. ${ }^{45}$ But public sale, particularly an auction sale, often fails to bring as high a price as does a private sale through normal channels of commerce ${ }^{46}$ where the lender can negotiate with businessmen who regularly buy products similar or identical to the collateral.

Secondly, the pledgee should be able to buy in the collateral at public sale. True, the lender may buy at an inadequate price. One solution would be to adopt the English rule of precluding any purchase of the collateral by the lender. ${ }^{47}$ But the danger of an inadequate bid is less in public sales than in private sales where the borrower has little opportunity to determine whether the lender might have obtained a higher offer. Moreover, in public sales the lender may pay a higher price than any competing bidder would be willing to pay, since the lender is likely to have better knowledge of the true value of the collateral. ${ }^{48}$ And he may bid high for fear that an inadequate price will lead to judicial invalidation. ${ }^{19}$

Courts should therefore preserve to borrowers and lenders the advantages of both public sales to pledgees and private sales to third persons, ${ }^{, 0}$ but should obviate the dangers inherent in such sales by prescribing rules for their con-

45. Segali, La réalisation amiable du gage 108-15 (1936).

46. See note 7 supra. Despite this fact, private sales are usually avoided by pledgees for fear that such sales will be challenged in the courts. Letter from Harold H. Kaufmann, Vice-President, Manufacturers Trust Co., New York, June 7, 1956, on file with Yalc Laze Journal.

47. Attenborough, Pawnbrokers 30 (1925) (this does not apply to loans under $£ 10$ made by pawnbrokers); 23 Halsbury, Laws of ENgland 439 (2d ed. 1936); AshBURNER, MORTGages 76 (2d ed. 1911). This rule has its roots in Roman law. Osborne, Mortgages $\$ 342$ n.8 (1951). Since he cannot buy the collateral himself, the English mortgagee "take[s] care he gets good value for the praperty, apart from any fear of action for improper sale." Turner, An English View of Mortgage Deficiency Judgments, 21 VA. L. REv. 601,605 (1935). As a result, suits to set aside foreclosure sales are relatively infrequent. See 23 HalsbuRY, op. cit. supra at 436 n.m; cases collected in 35 ENGLISH AND EMPIRE DIGEst 499-505 (1927); 37 id. 14-17.

48. See Cole v. Manufacturers Trust Co., 164 Misc. 741, 747, 299 N.Y. Supp. 418, 426 (Sup. Ct. 1937) (purpose of allowing pledgee to bid is to stimulate competition) ; see also WALsm, MoRTGages 350 (1934) (mortgagee should be able to protect his security by bidding up the sale). This argument has less validity in private sales than in public sales, since private sales through usual commercial channels are better calculated to reach trade buyers whose experience will help them recognize the value of the collateral.

49. Turner, supra note 47 (recognizing "fear of action for improper sale" as a factor influencing the pledgee's bidding).

50. The fact that in well over half of all public foreclosure sales the secured party becomes the buyer emphasizes the need to encourage both better advertised public sales and private sales to third persons; persons who attend public sales are seldom aware of the true value of the collateral, and thus the security is often sold for an unnecessarily low price. 
duct. $^{.1}$ The pledgee should be required to advertise the collateral ${ }^{52}$ and to give timely notice to the pledgor of the time, place, and manner of sale. ${ }^{53}$ Notice gives the pledgor every opportunity of redemption, provides ample opportunity for both parties to look for potential buyers, and, at least in case of public sales, permits the borrower to attend the sale to assure that it is conducted proper$1 y .{ }^{54}$ Public advertisement should also be required in all cases. The advertisement should of course specify the time, manner and place of sale. It should identify the collateral and the pledgee. ${ }^{n}$ The collateral should be described in

51. In noncommercial situations, French law permits the pledgee to buy the collateral, but only at a price set by an independent appraiser. SEGALL, LA RÉALISATION AMIABLE DU GAGE 51-52 (1946). Although appraisal may be helpful, it should not be mandatory. The pledgee should be able to buy readily marketable collateral at private sale without incurring the cost of appraisal in each case, since the pledge's value can be determined whenever inadequacy of price is alleged. See note 28 supra. And in other cases, it seems unlikely that a sale with appraisal will net a higher price than that obtainable at a sale conducted under rules designed to attract competitive bids. See notes 54-60 infra and accompanying text.

52. The advertisement requirements proposed herein will, of course, increase the cost of foreclosure. In large loans, the cost is, percentage-wise, a reasonable price of safeguarding borrowers. And pawnbrokers, who normally have a high volume of small loans and a high volume of foreclosures, can readily distribute the cost of advertising collateral of little value. In fact, all states regulate pawnbrokers, many requiring public auctions, advertising or other safeguards. For a discussion of the problem, a digest of the state laws, and a proposed Uniform Pawnbroking Bill, see Raby, The Regulation of Pawnbroking (1924). But other lenders-primarily commercial banks-whose relatively small volume will not permit wide distribution of advertising costs should not be required to advertise collateral pledged to secure loans of, for instance, $\$ 100$ or less.

53. Notice of sale should be deemed sufficient if in writing, and either (a) personally served on the pledgor, or (b) sent by ordinary mail to his last known busine'ss address. See Uniforar Trust Recerpts Act $\$ 6(3)$ (b) ; United States Trust Co. v. Blundon, 42 App. D.C. 500, 507 (1914) (pledgee must show that notice was mailed). Contra, Stearns v. Marsh, 4 Denio 227 (N.Y. 1847) (if the pledgur cannot be found, judicial foreclosure must be resorted to in the absence of a waiver of notice).

54. National Bank v. Baker, 128 I1l. 533, 21 N.E. 510 (1889); Dimock v. United States Nat'l Bank, 55 N.J.L. 296, 25 Atl. 926 (1896) ; Davis v. Funk, 39 Pa. 243 (1861). See Brown, Personal Property 658 (2d ed. 1955) ; Colbbrooke, Collateral Securuties 221 (2d ed. 1898).

55. See Seasongood, Drastic Pledge Agreements, 29 Harv. L. Rev. 277, $282-83$ (1916). The author proposes that the advertisement should, in addition, disclose the pledgor's name, the fact that this is a pledge foreclosure, and the amount of the debt.

"If ... a considerable sum has been advanced on the assumed worth of the pledge, this tends to appreciate the value of the pledged security in the eyes of the public. While, of cutrse the lender may have relied largely on the financial strength of the maker of the obligation and but little on the security, yet the converse may be true, and only by knowing all the facts can the public make up its mind which is probably the case."

Ibid. See Wade v. Markwell \& Co., 188 Cal. App. 2d 410, 258 P.2d 497 (1953) (advertisement should contain statement of amount of debt). This idea is sometimes used in real estate mortgage foreclosures. See N.Y. REAL. Property LAw \$ 544; statutes collected in Walsh, Mortgages 345 (1934). But in the pledge context the amount of the debt is too 
sufficient detail to attract inquiry from potential buyers. I'hen the collateral consists of stock, the advertisement should state the number of shares or, if a controlling interest is involved, the percentage of outstanding shares being offered $:^{56}$ and it should describe the corporation's principal asset-for example, the location and size of real estate in the case of a holding company or the principal product and plant capacity of a manufacturer. ${ }^{57}$ In other cases, the description should again be as specific as a short classified advertisement can be-the weight, cut and color of a diamond, the style and type of pelt in a fur coat, 58 the maker, face amount, rate of interest, date and maturity of a promissory note. ${ }^{59}$ To enable prospective bidders to investigate further before the sale, the advertisement should state how, and from whom, they can obtain further information. The lender should be required to advertise that information can be obtained directly from the pledgor or a person designated by him; for the pledgor usually has the best information on the value of the collateral and the opportunity to contact inquirers himself will preclude a later claim that the lender withheld information in order to suppress bids from outsiders. Thus the lender should be required to notify the pledgor before advertising in order to permit him to decide whether the advertisement should give his own name or that of his nominee. To attract buyers as well as to permit investigation the lender should continue the advertisements for a reasonable period before selling the collateral. ${ }^{\text {o }}$

often misleading, not only for the reason stated by Seasongood himself, but also because the collateral may have greatly depreciated in value, between the time the loan is made and the time of foreclosure.

56. See In the Matter of Kiamie, 309 N.Y. 325, 130 N.E.2d 745 (1955). See also Jennings, Trading in Corporate Control, 44 CALIF. L. Rev. 1 (1956) (showing that the price paid for controlling stock often greatly exceeds the quoted market value).

57. The advertisement need contain neither all the information a careful investor would require before buying, nor the disclosure required by the Securities Act of 1933. It should contain enough easily available information to identify the collateral and thereby spur potential buyers to investigate.

In some circumstances, however, a pledgee foreclosing on collateral might be subject to the disclosure requirements of $\S 10$ of the Securities Act of 1933. 48 Srat. 81, 15 U.S.C. $\S 77(j)$ (1952). If the collateral consisted of a controlling interest in a corporation, the pledgee might be regarded as an underwriter under $\S 2(11)$. The statute probably does not confer underwriter status on the pledgee when the loan is made. Loss, Securitres Regulation 346 (1951); Throop \& Lane, Some Problems of Excmption under the Securities Act of 1933, 4 LAW \& ConteMr. Prob. 89, 124 (1937). However, when the collateral is sold, the broad disclosure policies behind the act might place the pledgee within the ambit of $\S 2(11)$. See In the Matter of Ira Haupt \& Co., SEC Release No. 3845 (Aug. 21, 1946).

58. Wade v. Markwell \& Co., 118 Cal. App. 2d 410, 258 P.2d 497 (1953) (collateral should have been advertised as a full length, natural Eastern mink coat).

59. Cf. Mechanics \& Metals Nat'1 Bank v. Pingree, 40 Idaho 118, 232 Pac. 5 (1924) (even this advertisement, however, was insufficient when it appeared only twice in a newspaper and the notes were sold in a distant market where makers were unknown).

60. In many states statutes may guide the courts in determining the sufficiency of the advertisement. See, e.g., N.Y. CIv. Prac. ACr $\$ 986$ (real estate must be advertised 
The courts, rather than the legislatures, should fix the standards for sales by pledgees. To be workable. a statute must be specific enough to accommodate both unusual circumstances and changes in business practices. The drafters of the Uniform Commercial Code apparently recognized that this is virtually impossible; the Code requires only commercial reasonableness, ${ }^{61}$ leaving to the courts the task of developing more specific standards. For this task the courts are well equipped. Since they announce their decisions in the context of specific factual situations, the courts can indicate the market conditions, business practices and other current economic conditions which influenced their decisions. Thus commercial lenders can be alerted to accommodate their foreclosure procedures to changing conditions. But if the courts fail to develop clear standards, the legislatures should regulate pledge foreclosures consistently with the interests of both parties. ${ }^{62}$

twice weekly for three weeks before judgment sale) ; ג.Y. LIEN LAw $\S 202$ (once a week for two consecutive weeks).

In the case of perishables, the requirements of advertisement should be relaxed. "Perishables" should be construed in the physical sense, not market value sense. In cases of rapidly falling market of stocks, advertising and notice requirements can always be set aside by mutual agreement. See note 42 supra. Since it is a matter of opinion whether or not stocks will continue to decline, a unilateral right to dispense with advertising and notice requirements could easily lead to abuse. See Small v. Housman, 208 N.Y. 115, 101 N.E. 700 (1913) (reasonable notice of sale required before stocks can be sold in declining market). But sec UNIFORM COMMrercial CODE $\$ 9-504(2)$ (notice required unless collateral is perishable or threatens to decline speedily in value).

For discussion of the problem of when the collateral must be sold, and how much of it can be sold if it is divisible, see Note, 41 Colum. L. Rev. 1087, 1090-91 (1941).

61. UNIFORM COMMRERCIAL CODE $\$ 9-504(2)$.

62. See Kessler, Contracts of Adhesion-Sone Thoughts about Freedom of Contract, 43 CoLus. L. REv. 629, 633 (1943) (noting that legislation became necessary in the insurance field because the courts caused too much uncertainty by trying to protect a party in an unequal bargaining position while, at the same time, struggling to respect freedom of contracts). 